\title{
Comparison of Off-site Radiological Dose Due to the Routine Release of Gaseous Radioactive Effluents Based on the Korean and Japanese Regulatory Recommendations
}

\author{
Won Tae Hwang', Chang Lak Kim², Cheol-Woo Lee', Moon Hee Han' \\ ${ }^{1}$ Korea Atomic Energy Research Institute, Daejeon, Korea; ${ }^{2}$ KEPCO International Nuclear Graduate School, Ulsan, Korea
}

\section{Original Research}

Received October 8, 2019

Revision December 10, 2019

Accepted December 11, 2019

Corresponding author: Won Tae Hwang

Korea Atomic Energy Research Institute, 111 Daedeok-daero 989 beon-gil, Yuseong-gu, Daejeon 34057, Korea Tel: +82-42-868-2344

Fax: +82-42-868-2370

E-mail:wthwang@kaeri.re.kr

This is an Open-Access article distributed under the terms of the Creative Commons Attribution NonCommercial License (http://creativecommons.org/ licenses/by-nc/3.0) which permits unrestricted noncommercial use, distribution, and reproduction in any medium, provided the original work is properly cited.

Copyright $\odot$ 2019The Korean Association for Radiation Protection

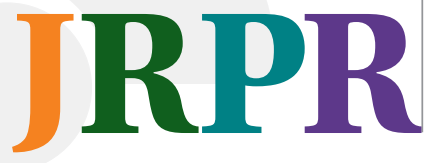

Background: Not only regulatory framework including radiation protection quantities and regulatory standards, but also methodology for regulatory compliance may be different in each country due to inherent philosophy for radiation protection.

Materials and Methods: Based on the Korean regulatory models, off-site radiological dose resulting from the routine releases of gaseous radioactive effluents was calculated by applying the parameter values and assumptions recommended in the Korean and Japanese regulations.

Results and Discussion: Effective dose for adult based on the Korean recommendation were 17.5 and 1.6 times higher than those of Japanese recommendation for ${ }^{131} \mathrm{I}$ and ${ }^{133} \mathrm{I}$, respectively, for the same atmosphere dispersion and ground deposition factors.

Conclusion: It was due to different parameter values and assumptions recommended for the purpose of evaluating compliance with dose criteria for the radiation protection of the public in each country.

Keywords: Regulatory Model, Gaseous Radioactive Effluent, Off-site Radiological Dose, Radioiodine, Design Stage

\section{Introduction}

Off-site radiological dose assessment is an essential element to identify the proper design of radioactive effluents system for the radiation protection of the public and the environment at the design stage of nuclear power plants. Not only regulatory framework including radiation protection quantities and regulatory standards, but also methodology for regulatory compliance may be different in each country due to inherent philosophy for radiation protection.

Methodology for the Korean off-site dose calculation is described in a reference [1]. Although mathematical models are basically similar to those recommended in the U. S. Nuclear Regulatory Commission (NRC) [2], inherent environmental characteristics including habits show a clear difference. The standards of off-site dose due to radioactive effluents are stated in a notice enacted by the Nuclear Safety and Security Commission (NSSC) in Korea [3]. On the other hand, methodology for the Japanese off-site dose cal- 
culation is described in a reference [4].

Radioiodines as gaseous effluents may be critical in the contribution of off-site dose at the design stage of nuclear power plants. They are mainly produced by the fission of nuclear fuels, and it assumes that a certain fraction from defected fuels is inevitably released into the environment. Radioiodines may be released to the atmosphere with a variety of chemical forms such as elemental and organic types, and their behaviors in the environment are more complex comparing with other radionuclides of particulate types.

In this study, parameter values and assumptions recommended in the Korean and Japanese regulatory guides, which may be required to calculate off-site dose due to gaseous effluents in case of no site-specific data, are compared and discussed. And off-site dose is calculated according to the recommendations of both countries using the same Korean regulatory models, and its results are compared.

\section{Materials and Methods}

Radionuclides released into the atmosphere can give rise to radiation exposure to the public through a variety of behaviors in environmental media such as air and soil. In the Korean regulation, the consideration of the following exposure pathways is required as major exposure pathways for gaseous effluents as:

- External exposure from air immersion

- External exposure from deposited ground

- Internal exposure from inhaled air

- Internal exposure from ingested food

On the other hands, in the Japanese regulation, external exposure from deposited ground is excluded as a major pathway.

\section{External Exposure from Air Immersion}

External dose by gamma and beta rays from contaminated air is only considered for noble gases. It is calculated as follows:

$$
D_{j}^{E C}=8,760 S F \sum_{i} C_{i}^{A} D F_{i j}^{E C}
$$

where,

$i$ : radionuclide

$j$ : organ

$D_{j}^{E C}:$ external dose from air immersion $\left(\mathrm{mSv} \cdot \mathrm{yr}^{-1}\right)$
$C_{i}^{A}:$ air concentration $\left(\mathrm{Bq} \cdot \mathrm{m}^{-3}\right)$

$D F_{i j}^{E C}$ : dose coefficient by air immersion $\left(\left[\mathrm{mSv} \cdot \mathrm{hr}^{-1}\right]\right.$ per $\left.\left[\mathrm{Bq} \cdot \mathrm{m}^{-3}\right]\right)$

$S F$ : shielding factor (dimensionless)

8,760 : unit conversion factor $\left(\mathrm{hr} \cdot \mathrm{yr}^{-1}\right)$

Shielding factor includes the fraction of spending time at indoor as well as radiation attenuation by residential structures. Air concentration is calculated as follows:

$$
C_{i}^{A}=\left(\frac{\chi}{Q}\right) \times Q_{i}
$$

where,

$\frac{\chi}{Q}$ : annual averaged atmospheric dispersion factor $\left(\mathrm{sec} \cdot \mathrm{m}^{-3}\right)$

$Q_{i}$ :release rate of radionuclides into the atmosphere $\left(\mathrm{Bq} \cdot \mathrm{sec}^{-1}\right)$

\section{External Exposure from Deposited Ground}

External dose by gamma and beta rays from contaminated ground due to deposition of radionuclides released into atmosphere is considered for all other radionuclides except noble gases, ${ }^{14} \mathrm{C}$ and ${ }^{3} \mathrm{H}$. It is calculated as follows:

$$
D_{j}^{E G}=8,760 S F \sum_{i} d_{i}\left[\frac{1-\exp \left(-\lambda_{i} T_{b}\right)}{\lambda_{i}}\right] D F_{i j}^{E C}
$$

where,

$D_{j}^{E G}$ : external dose from deposited ground $\left(\mathrm{mSv} \cdot \mathrm{yr}^{-1}\right)$

$T_{b}$ : mid-point of soil exposure (sec)

$d_{i}$ : deposition rate onto the ground $\left(\mathrm{Bq} \cdot\left(\mathrm{m}^{2} \cdot \mathrm{sec}\right)^{-1}\right)$

$\lambda_{i}:$ radioactive decay constant $\left(\mathrm{sec}^{-1}\right)$

$D F_{i j}^{E C}$ : dose coefficient by deposited ground $\left(\left[\mathrm{mSv} \cdot \mathrm{hr}^{-1}\right]\right.$ $\left.\operatorname{per}\left[\mathrm{Bq} \cdot \mathrm{m}^{-2}\right]\right)$

Deposition rate onto the ground is calculated as follows:

$$
d_{i}=\left(\frac{D}{Q}\right) \times Q_{i}
$$

where

$\frac{D}{Q}$ : annual averaged deposition factor $\left(\mathrm{m}^{-2}\right)$

As previously mentioned, this pathway is not considered as a major pathway in the Japanese regulation.

\section{Internal Exposure from Inhaled Air}

Inhalation dose by the breathing of contaminated air is considered for all other radionuclides except noble gases. It 
is calculated as follows:

$$
D_{j k}^{I H}=B R_{k} \sum_{i} C_{i}^{A} D F_{i j k}^{I H}
$$

where,

$k$ : age group

$D_{j k}^{I H}:$ inhalation dose $\left(\mathrm{mSv} \cdot \mathrm{yr}^{-1}\right)$

$B R_{k}$ : annual breathing rate $\left(\mathrm{m}^{3} \cdot \mathrm{yr}^{-1}\right)$

$D F_{i j k}^{I H}$ : dose coefficient by inhalation $\left(\mathrm{mSv} \cdot \mathrm{Bq}^{-1}\right)$

\section{Internal Exposure from Ingested Food}

Ingestion dose by the consumption of contaminated food is considered for all other radionuclides except noble gases. It is calculated as follows:

$$
D_{j k l}^{I G}=F_{l} U_{k l} \sum_{i} C_{i l} D F_{i j k}^{I G}
$$

where,

$l$ : food

$D_{j k l}^{I G}$ : ingestion dose by food consumption $\left(\mathrm{mSv} \cdot \mathrm{yr}^{-1}\right)$

$F_{l}$ : consumption fraction of contaminated food (dimensionless)

$U_{k l}$ : annual food consumption rate $\left(\mathrm{L} \cdot \mathrm{yr}^{-1} \mathrm{or} \mathrm{kg} \cdot \mathrm{yr}^{-1}\right)$

$C_{i l}$ : radionuclide concentration in food $\left(\mathrm{Bq} \cdot \mathrm{L}^{-1}\right.$ or $\left.\mathrm{Bq} \cdot \mathrm{kg}^{-1}\right)$

$D F_{i j k}^{I G}$ : dose coefficient by ingestion $\left(\mathrm{mSv} \cdot \mathrm{Bq}^{-1}\right)$

Radionuclide concentration in food is predicted by using different models depending on radionuclides. ${ }^{3} \mathrm{H}$ and ${ }^{14} \mathrm{C}$ are not considered for the regulatory purposes at design stage in Japan. Thus, regulatory models for these radionuclides is not described in this paper. Radionuclide concentration in agricultural product $\left(C_{i l}^{A}, \mathrm{~Bq} \cdot[\mathrm{kg} \text {-wet weight }]^{-1}\right)$ for particulates is predicted as follows:

$C_{i l}^{A}=\left(\frac{d_{i} r}{Y_{v} \lambda_{e i}}\left[1-\exp \left(-\lambda_{e i} T_{e}\right)\right]+\frac{d_{i} B_{v i}}{P \lambda_{i}}\left[1-\exp \left(-\lambda_{i} T_{b}\right)\right]\right) \exp \left(-\lambda_{i} T_{h}\right)$

where,

$r$ : fraction of radionuclide retained on agricultural product (dimensionless)

$Y_{v}$ : yield of agricultural product $\left([\mathrm{kg}\right.$-wet weight $\left.] \cdot \mathrm{m}^{-2}\right)$

$\lambda_{e i}$ : effective removal constant $\left(=\lambda_{w}+\lambda_{i}, \sec ^{-1}\right)$

$\lambda_{w}$ : removal constant by weathering $\left(\sec ^{-1}\right)$

$T_{e}$ : growing period of agricultural product (sec)

$T_{h}$ : holdup time from harvest to consumption (sec)

$P$ : effective surface density of soil $\left([\mathrm{kg}\right.$-soil $\left.] \cdot \mathrm{m}^{-2}\right)$

$B_{v i}$ : soil concentration factor $\left([\mathrm{kg}\right.$-soil $\left.] \cdot[\mathrm{kg} \text {-wet weight }]^{-1}\right)$
Radionuclide concentration in livestock product $\left(C_{i v}^{L} \mathrm{~Bq} \cdot \mathrm{L}^{-1}\right.$ or $\left.\mathrm{Bq} \cdot \mathrm{kg}^{-1}\right)$ is predicted as follows:

$C_{i l}^{L}=T_{i l}^{F M} q_{l}\left[C_{i l}^{P} f_{l} f_{l}^{P}+C_{i l}^{F}\left\{f_{l}\left(1-f_{l}^{P}\right)+\left(1-f_{l}\right)\right\}\right] \exp \left[-\lambda_{i}\left(T_{s}+T_{h}\right)\right](8)$

where,

$T_{i l}^{F M}$ : transfer coefficient of radionuclide to livestock products $\left(\mathrm{d} \cdot \mathrm{kg}^{-1}\right.$ or $\left.\mathrm{d} \cdot \mathrm{L}^{-1}\right)$

$q_{l}$ : consumption rate of livestock $\left(\mathrm{kg} \cdot \mathrm{d}^{-1}\right)$

$C_{i l}^{P}$ : radionuclide concentration in pasture $\left(\mathrm{Bq} \cdot \mathrm{kg}^{-1}\right)$

$f$ : fraction of annual grazing time in pasture (dimensionless)

$f_{l}^{P}$ : consumption fraction of contaminated pasture (dimensionless)

$C_{i l}^{F}$ : radionuclide concentration in stored feed $\left(\mathrm{Bq} \cdot \mathrm{kg}^{-1}\right)$

$T_{s}$ : storage period of feed (sec)

Eight kinds of food (grain, leafy vegetable, fruit, Kimchi [Chinese cabbage], milk, beef, pork, chicken) are considered in the Korean regulation. While, only two kinds of food (leafy vegetable, milk) are considered in the Japanese regulation, assuming that the remainder of food is not significant in dose contribution.

\section{Results and Discussion}

Based on the Korean regulatory models, off-site dose in terms of effective dose was calculated by applying the parameter values and assumptions recommended in the Korean and Japanese regulations in case of no site-specific data. Radioiodines $\left({ }^{131} \mathrm{I}\right.$ and ${ }^{133} \mathrm{I}$ ) were selected for the comparison of results, which may significantly contribute in off-site dose at design stage of nuclear power plants. ${ }^{131} \mathrm{I}$ and ${ }^{133} \mathrm{I}$ have relatively short half-life of 8 days and 20 hours, respectively. Age group was selected as adult. Annual averaged atmospheric dispersion factor and deposition factor were assumed to be $1.0 \times 10^{-6} \mathrm{sec} \cdot \mathrm{m}^{-3}$ and $1.0 \times 10^{-8} \mathrm{~m}^{-2}$, respectively.

The Japanese regulatory models show a big difference compared with Korean ones. As an example, radionuclide concentration in agricultural products is predicted by distinguishing contamination of above-ground parts and contamination of below-ground parts in the Korean regulatory model, as shown in Equation (7). While, it is directly predicted from transfer rate from air to agricultural products obtained from experiments in the Japanese regulatory model. For this reason, all of parameter values to be required in the 
Table 1. Parameter Values and Assumptions Recommended in the Korean and Japanese Regulations for Off-site Dose Calculation [4, 5]

\begin{tabular}{|c|c|c|}
\hline Parameter & $\begin{array}{l}\text { Korean } \\
\text { recommendation }\end{array}$ & $\begin{array}{l}\text { Japanese } \\
\text { recommendation }\end{array}$ \\
\hline Breathing rate $\left(\mathrm{m}^{3} \cdot \mathrm{yr}^{-1}\right)$ & 8,100 & 8,100 \\
\hline Shielding factor & 0.7 & 1.0 \\
\hline $\begin{array}{l}\text { Consumption rate } \\
\left(\mathrm{kg} \cdot \mathrm{yr}^{-1} \text { or } \mathrm{L} \cdot \mathrm{yr}^{-1}\right)\end{array}$ & $\begin{array}{l}\text { Grain: } 160 \\
\text { Fruit: } 97 \\
\text { Kimchi: } 89.9 \\
\text { Leafy vegetables: } 161.8 \\
\text { Beef: } 15.7 \\
\text { Pork: } 28.8 \\
\text { Chicken: } 26.6 \\
\text { Milk: } 73.2\end{array}$ & $\begin{array}{l}\text { Leafy vegetables: } 36.5 \\
\text { Milk: } 73\end{array}$ \\
\hline $\begin{array}{l}\text { Fraction of } \\
\text { contaminated foods }\end{array}$ & $\begin{array}{l}\text { Grains: } 0.9 \\
\text { Leafy vegetables: } 0.76 \\
\text { Pork: } 1.0 \\
\text { Chicken: } 1.0 \\
\text { Others: } 1.0\end{array}$ & $\begin{array}{l}\text { Leafy vegetables: } 0.25^{*} \\
\text { Milk: } 0.25^{\dagger}\end{array}$ \\
\hline $\begin{array}{l}\text { Holdup time from } \\
\text { harvest to } \\
\text { consumption (day) }\end{array}$ & $\begin{array}{l}\text { Grain/Fruit/Kimchi: } 14 \\
\text { Leafy vegetables: } 1 \\
\text { Beef/Pork: } 7 \\
\text { Chicken: } 3 \\
\text { Milk: } 1\end{array}$ & Not considered \\
\hline Yields ([wet-kg] · m²) & $\begin{array}{l}\text { Grains: } 0.36 \\
\text { Fruits: } 0.13 \\
\text { Kimchi: } 4.53 \\
\text { Leafy vegetables: } 4.52 \\
\text { Pasture: } 4.0\end{array}$ & Leafy vegetables: 2.3 \\
\hline $\begin{array}{l}\text { Weathering half-life } \\
\text { (day) }\end{array}$ & 14 & 13 \\
\hline
\end{tabular}

*Annual fraction of cultivating period and decontamination factor are assumed to be 0.5 and 0.5 , respectively.

${ }^{\dagger}$ Market dilution factor, mixing fraction of feeds and annual fraction of cultivating period of pasture are assumed to be $0.5,1.0$, and 0.5 , respectively.

Korean regulatory models do not provide in the Japanese regulatory guide. Thus, off-site dose was calculated by using available parameter values and assumptions to the Korean regulatory models provided in the Japanese regulatory guide, as shown in Table 1. In addition, it includes parameter values and assumptions differentiated in the Korean recommendation for the comparison with Japanese one. Other parameter values are provided in a reference [5].

The most important difference between the recommendations of the two countries is evaluation target (person) for radiation protection of the public. The evaluation target in the Korean regulation is maximum exposed individual, which coincides with a concept applied to the U.S. NRC's regulation. While, it is typical individual in the Japanese regulation, which is similar to a concept recommended in the International Commission on Radiological Protection (ICRP) [6].
Table 2. Dose Coefficients by Inhalation and Ingestion [4, 5]

\begin{tabular}{ccc}
\hline \multirow{2}{*}{ Pathway } & \multicolumn{2}{c}{ Dose coefficient $\left(\mathrm{mSv} \cdot \mathrm{Bq}^{-1}\right)$} \\
\cline { 2 - 3 } & Korean recommendation & Japanese recommendation \\
\hline Inhalation & & \\
I-131 & $2.0 \times 10^{-5}$ & $1.5 \times 10^{-5}$ \\
I-133 & $4.0 \times 10^{-6}$ & $2.9 \times 10^{-6}$ \\
Ingestion & & \\
I-131 & $2.2 \times 10^{-8}$ & $1.6 \times 10^{-8}$ \\
I-133 & $4.3 \times 10^{-9}$ & $3.1 \times 10^{-9}$ \\
\hline
\end{tabular}

Table 3. Off-site Dose for ${ }^{131}$ I Calculated according to the Korean and Japanese Recommendations

\begin{tabular}{|c|c|c|c|}
\hline \multirow{2}{*}{$\begin{array}{l}\text { Exposure } \\
\text { pathway }\end{array}$} & \multicolumn{2}{|c|}{ Off-site dose $\left(\left[\mathrm{mSv} \cdot \mathrm{yr}^{-1}\right]\right.$ per $\left.\left[\mathrm{Bq} \cdot \mathrm{yr}^{-1}\right]\right)$} & \multirow{2}{*}{$\begin{array}{l}\text { Ratio } \\
\text { (A/B) }\end{array}$} \\
\hline & $\begin{array}{c}\text { Korean } \\
\text { recommendation }(\mathrm{A})\end{array}$ & $\begin{array}{c}\text { Japanese } \\
\text { recommendation (B) }\end{array}$ & \\
\hline Air immersion & $1.19 \times 10^{-17}$ & $1.69 \times 10^{-17}$ & 0.70 \\
\hline Ground deposition & $1.27 \times 10^{-15}$ & Not considered & - \\
\hline Inhalation & $5.14 \times 10^{-15}$ & $3.85 \times 10^{-15}$ & 1.34 \\
\hline \multicolumn{4}{|l|}{ Ingestion } \\
\hline Agricultural products & $2.13 \times 10^{-13}$ & $6.24 \times 10^{-15}$ & 34.13 \\
\hline Milk & $9.03 \times 10^{-15}$ & $3.47 \times 10^{-15}$ & 2.60 \\
\hline Meat & $8.60 \times 10^{-15}$ & Not considered & - \\
\hline Total & $2.30 \times 10^{-13}$ & $9.71 \times 10^{-15}$ & 23.75 \\
\hline Total & $2.37 \times 10^{-13}$ & $1.36 \times 10^{-14}$ & 17.46 \\
\hline
\end{tabular}

In the Korean recommendation, it is assumed that radioiodines released into the atmosphere are all of elemental type. However, in deposition on the ground and agricultural products, it is assumed that non-elemental type is $50 \%$ and it is not deposited. In the Japanese recommendation, organic type of $100 \%$ is assumed in the calculation of inhalation dose, however, inorganic type of $100 \%$ is assumed in the calculation of deposition. Table 2 shows the dose coefficients by inhalation and ingestion recommended in Korean and Japanese regulation.

Off-site dose was calculated according to the recommendations of both countries using the Korean regulatory models. The results are shown in Tables 3 and 4.

The greatest difference was found in ingestion dose by the consumption of agricultural products for both radioiodines. The results based on the Korean recommendation were higher than those based on the Japanese recommendation, except for the external dose by air immersion. Shielding effects are not considered in the calculation of external dose by air immersion in the Japanese recommendation. From the results, it was found that the holdup time from harvest to consumption is a critical parameter for short half-life radionuclides. Total doses based on the Korean recommendation 
Table 4. Off-site Dose for ${ }^{133}$ | Calculated according to the Korean and Japanese Recommendations

\begin{tabular}{|c|c|c|c|}
\hline \multirow{2}{*}{$\begin{array}{l}\text { Exposure } \\
\text { pathway }\end{array}$} & \multicolumn{2}{|c|}{ Off-site dose $\left(\left[\mathrm{mSv} \cdot \mathrm{yr}^{-1}\right]\right.$ per $\left.\left[\mathrm{Bq} \cdot \mathrm{yr}^{-1}\right]\right)$} & \multirow{2}{*}{$\begin{array}{l}\text { Ratio } \\
\text { (A/B) }\end{array}$} \\
\hline & $\begin{array}{c}\text { Korean } \\
\text { recommendation }(A)\end{array}$ & $\begin{array}{c}\text { Japanese } \\
\text { recommendation (B) }\end{array}$ & \\
\hline Air immersion & $1.93 \times 10^{-17}$ & $2.75 \times 10^{-17}$ & 0.70 \\
\hline Ground deposition & $2.31 \times 10^{-16}$ & Not considered & - \\
\hline Inhalation & $1.03 \times 10^{-15}$ & $7.45 \times 10^{-16}$ & 1.38 \\
\hline \multicolumn{4}{|l|}{ Ingestion } \\
\hline Agricultural products & $3.49 \times 10^{-16}$ & $1.98 \times 10^{-16}$ & 1.76 \\
\hline Milk & $1.38 \times 10^{-16}$ & $1.10 \times 10^{-16}$ & 1.25 \\
\hline Meat & $7.57 \times 10^{-19}$ & Not considered & - \\
\hline Total & $4.88 \times 10^{-16}$ & $3.08 \times 10^{-16}$ & 1.58 \\
\hline Total & $1.77 \times 10^{-15}$ & $1.08 \times 10^{-15}$ & 1.64 \\
\hline
\end{tabular}

were 17.5 and 1.6 times higher than those of the Japanese recommendation for ${ }^{131} \mathrm{I}$ and ${ }^{133} \mathrm{I}$, respectively.

\section{Conclusion}

Based on the Korean regulatory models, off-site dose from the routine releases of gaseous effluents was calculated by applying the parameter values and assumptions recommended in the Korean and Japanese regulations. It was found that off-site dose for each exposure pathway shows a clear difference for the same atmosphere dispersion and ground deposition factors, especially in ingestion dose by the consumption of agricultural products. Off-site doses based on the Korean recommendation was higher than those based on the Japanese recommendation for radioiodines, which are critical contributing radionuclides in off-site dose at design stage of nuclear power plants. It was due to different parameter values and assumptions recommended in the two countries for the purpose of evaluating compliance with dose criteria for the radiation protection of the public. The results would serve for the further improvement of the Korean regulation.

\section{Acknowledgements}

This work was supported by Nuclear R\&D programs of the Ministry of Science and ICT of Korea (Grant No. 2017M2A8A4015251), and the Nuclear Safety Research Program through the Korea Foundation of Nuclear Safety (KOFONS) granted financial resources from the Nuclear Safety and Security Commission (NSSC) of Korea (Grant No. 1605008).

\section{References}

1. Korean Institute of Nuclear Safety. Regulation Standards and Guides for Light Water Nuclear Reactors. KINS/RG-N02.02, Rev. 2. 2016.

2. U. S. Nuclear Regulatory Commission, Calculation of Annual Doses to Man from Routine Releases of Reactor Effluents for the Purpose of Evaluating Compliance with 10 CFR Part 50, Appendix I, Regulatory Guide 1.109. 1976.

3. Nuclear Safety and Security Commission. Standards for Radiation Protection. NSSC Notice 2019-10, 2019.

4. Nuclear Safety Commission of Japan. Reviewing Evaluation of Dose Target for Surrounding Area of Light Water Reactor Facilities. NSCRG : L-RE-1.01. 2001.

5. Korean Institute of Nuclear Safety. supplement and V\&V of Integrated Dose Assessment Code package. KINS/HR-1357. 2014.

6. International Commission on Radiation Protection. Recommendations of the International Commission on Radiation Protection. ICRP Publication No. 60. 1991. 